Jurnal Progres Ekonomi Pembangunan (JPEP)

Volume 6, Nomor 1. Tahun 2021

Page: $13-25$

http://ojs.uho.ac.id/index.php/JPEP

\title{
KAUSALITAS NILAI TUKAR, JUMLAH UANG BEREDAR DAN INFLASI DI NEGARA ASEAN-5
}

\author{
Burhanuddin \\ Program Studi Ilmu Ekonomi Pascasarjana Universitas Halu Oleo Kendari \\ Email: burhan038@gmail.com \\ Rostin \\ Fakultas Ekonomi dan Bisnis Universitas Halu Oleo Kendari \\ Email: drrostintin@gmail.com \\ Manat Rahim \\ Fakultas Ekonomi dan Bisnis Universitas Halu Oleo Kendari \\ Email: arifmanat@gmail.com \\ Rosnawintang \\ Fakultas Ekonomi dan Bisnis Universitas Halu Oleo Kendari \\ Email: nanarosnawintang@yahoo.co.id
}

\begin{abstract}
Abstrak
Penelitian ini bertujuan menganalisis hubungan kausalitas nilai tukar, inflasi IHK dan jumlah uang beredar (M2) di Negara ASEAN-5. Jenis data yang digunakan dalam penelitian ini yaitu data sekunder yang diakses dari webside investing.com, ceicdata.com dan trandingeconomic.com. Data yang digunakan adalah time series bulanan periode 2010.1 sampai 2018.12. Alat analisis yang digunakan yaitu Panel Vector Auto Regretion (VAR). Hasil penelitian menunjukkan (1) Terdapat hubungan kausalitas antara jumlah uang beredar dan inflasi serta hubungan kausalitas satu arah nilai tukar terhadap jumlah uang beredar dan nilai tukar terhadap inflasi; (2) Dalam jangka pendek nilai tukar berpengaruh signifikan terhadap jumlah uang beredar. Dalam jangka panjang jumlah uang beredar dan inflasi berpengaruh signifikan terhadap nilai tukar, jumlah uang beredar berpengaruh signifikan terhadap inflasi serta inflasi berpengaruh signifikan terhadap jumlah uang beredar.
\end{abstract}

Kata Kunci: Nilai Tukar, Inflasi IHK, Jumlah Uang Beredar (M2), Panel VAR.

The purpose of this study is to analyze the causality relationship of exchange rates, IHK inflation and money supply (M2) in ASEAN-5. The type of data in this study is secondary data accessed from the webside investing.com, ceicdata.com and trandingeconomic.com. The data uses a monthly time series from 2010.1 until 2018.12. The data analyze is Panel Vector Auto Regretion (VAR). The results is (1) There is a causal relationship of money supply and inflation and There is a one-way causal relationship of exchange rates to money supply and exchange rates to inflation; (2). In the short term the exchange rate significant affect on money supply. In the long run money supply on inflation the exchange rate, money supply significant affect on inflation and inflation significant affect on money supply.

Keywords: Exchange Rate, IHK Inflation, Money Supply (M2), Panel VAR.

\section{PENDAHULUAN}

Sistem perekonomian terbuka yang dianut oleh Negara-Negara ASEAN yang tercantum dalam Masyarakat Ekonomi Asean (MEA). Bentuk perjanjian tersebut merupakan sebuah intergrasi ekonomi ASEAN dalam menghadapi perdagangan bebas antar sesama negara-negara ASEAN. MEA atau AEC merupakan salah satu bentuk kerjasama Negara-Negara ASEAN 
Jurnal Progres Ekonomi Pembangunan (JPEP)

Volume 6, Nomor 1. Tahun 2021

Page: $13-25$

http://ojs.uho.ac.id/index.php/JPEP

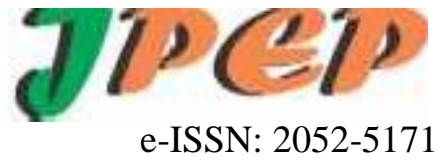

dibidang Ekonomi, masyarakat Ekonomi ASEAN "MEA" sendiri telah dibuka pada Desember 2015 lalu dengan tujuan untuk mewujudkan wawasan ASEAN pada tahun 2020.

Kondisi makro ekonomi negara-negara ASEAN menurut data menunjukkan bahwa terjadi keterkaitan antara variabel makro ekonomi. Pada tahun 2017 tingkat inflasi yang terjadi di Thailand sebesar 0,78\%; Singapura 0,40\%; Malaysia 3,50\%; Filipina 2,90\% dan Indonesia 3,20\%. Pada tahun 2018 terjadi perubahan yaitu Thailand 0,36\%; Singapura 0,50\%; Malaysia 0,20\%; Filipina 5,10\% dan Indonesia 3,49\% (www.trandingeconomics.com, 2019). Kondisi juga terjadi pada jumlah uang beredar yang mengalami perubahan. Pada tahun 2017 jumlah uang beredar di Thailand sebesar 589.053.792 USD; Singapura 431.082.974 USD; Malaysia 424.393.891 USD; Filipina 202.447.935 USD dan Indonesia 5.419.165.050 USD. Pada tahun 2018 terjadi peningkatan yaitu Thailand 614.827.136 USD; Singapura 439.838.441 USD; Malaysia 452.191.080 USD; Filipina 209.975.056 USD dan Indonesia 5.760.046.200 USD (www.ceicdata.com, 2019). Kondisi tersebut juga terjadi pada nilai tukar mata uang negara terhadap USD pada tahun 2017 nilai mata uang Thailand sebesar 32,560; Singapura 1,338; Malaysia 4,047; Filipina 50,014 dan Indonesia 13.567,5. Pada tahun 2018 terjadi perubahan yaitu Thailand 32.340; Singapura 1,363; Malaysia 4,133; Filipina 52,5 dan Indonesia 14.380 (www.investing.com, 2019).

Inflasi merupakan dampak dari tingginya jumlah uang yang beredar di masyarakat yang tercermin dari teori Irving Fisher. Menurut Reksoprayitno (2009) dalam kondisi deflasi, tingkat harga akan cenderung mengalami penurunan, sedangkan nilai riil dari jumlah uang beredar akan mengalami peningkatan. Dengan tingginya jumlah uang yang berdar dimasyarakat akan mengakibatkan semakin menurunnya nilai dari uang tersebut. Hubungan keterkaitan antara inflasi dan jumlah uang beredar diteliti pula oleh Theodores, dkk. (2014) dimana dalam penelitainnya menunjukkan bahwa jumlah uang beredar berpengaruh positif namun tidak signifikan terhadap tingkat inflasi yang terjadi di Indonesia. Berbeda halnya dengan penelitian yang dilakukan oleh Hario (2010) menggunakan metode Ordinary Least Square (OLS) menemukan bahwa jumlah uang beredar berpengaruh negatif terhadap tingkat inflasi yang terjadi.

Interaksi jumlah uang beredar dan nilai nilai tukar dilakukan oleh Hendayanti, dkk (2017) menyatakan bahwa nilai nilai tukar berpengaruh terhadap jumlah uang beredar. Hal ini dapat diartikan ketika rupiah melemah pada bulan sebelumnya akan ada kecenderungan seseorang untuk menukarkan dolar yang dimiliki sehingga orang tersebut akan mendapatkan keuntungan yang lebih besar. Hal ini yang mengakibatkan jumlah uang beredar mengalami kenaikan. Sebalikya Musyaffa dan Sulasmiyati (2017) menyatakan bahwa jumlah uang beredar berpengaruh terhadap nilai tukar. Sehingga jumlah uang beredar (M2) yang meningkat akan mendepresiasi nilai tukar terhadap dollar Amerika.

Menurut Ningsih dan Kristiyanti (2018) menyatakan dalam penelitiannya bahwa nilai tukar berpengaruh terhadap tingkat inflasi yang terjadi. Hal ini menunjukkan bahwa dengan tingginya tingkat inflasi akan mengakibatkan terdepresiasinya nilai tukar yang dikarenakan tingkat inflasi yang tinggi akan menyebabkan meningkatnya permintaan nilai tukar mata uang asing. Nilai mata uang yang menurun dapat mengakibatkan barang-barang produksi lokal (dalam negeri) yang mempunyai kandungan impor tinggi akan mengalami kenaikan biaya produksiyang menyebabkan harga jual kepada konsumen meningkat. Harga barang-barang yang terus mengalami kenaikanakan menyebabkan konsumsi masyarakat menurun. Maka dapat disimpulkan bahwa nilai tukar berpengaruh terhadap inflasi.

Penelelitan yang dilakukan oleh Hazizah, dkk (2017) mengemukakan bahwa inflasi yang terjadi berpengaruh terhadap nilai tukar. Apabila Inflasi domestik yang meningkat akan 
Jurnal Progres Ekonomi Pembangunan (JPEP)

Volume 6, Nomor 1. Tahun 2021

Page: $13-25$

http://ojs.uho.ac.id/index.php/JPEP

mengakibatkan nilai tukar terdepresiasi sebaliknyaapabilai inflasi luar negeri meningkat maka akan mengakibatkan nilai tukar Rupiah terapresiasi karena Inflasi yang tinggi disuatu Negara akan menyulitkan kalkulasi perencanaan bisnis sehingga berdampak buruk bagi aktifitas perekonomian dalam jangka panjang (Pratiwi dan Santoso, 2012 dalam Hazizah. dkk, 2017).

Tujuan yang hendak dicapai dalam penelitianini yaitu 1) Menganalisis hubungan kausalitas antara nilai tukar, jumlah uang beredar dan inflasi di Negara ASEAN-5 serta melihat goncangan (shock) akibat adanya gangguan dari masing-masing variabel; 2) Menganalisis hubungan jangka panjang dan jangka pendek antara nilai tukar, jumlah uang beredar dan inflasi di Negara ASEAN-5.

\section{KAJIAN LITERATUR DAN HIPOTESIS Kebijakan Moneter}

Kebijakan moneter merupakan sebuah proses yang dilakukan oleh otoritas meoneter suatu negara dalam rangka mengontrol/mengendalikan jumlah uang beredar, dengan pentargetan tingkat suku bunga dengan tujuan mendorong stabilitas dan pertumbuhan ekonomi. Litteboy and Taylor (1995) dalam Natsir (2012) mengemukakan bahwa kebijakan moneter merupakan upaya atau tindakan Bank Sentral dalam mengendalikan perkembangan moneter (jumlah uang beredar suku bunga, kredit dan nilai tukar) untuk mencapai tujuan ekonomi yang meliputi: pertumbuhan ekonomi stabilitas mata uang dan keseimbangan eksternal serta perluasan kesempatan kerja.

\section{Teori Fisher}

Teori fisher berpandangan bahwa mekanisme transisi kebijakan moneter bersifat langsung, jumlah uang beredar dan pertumbuhannya merupakan penyebab utama inflasi (Marshall and Swanson,1980 dalam Natsir, 2012). Teori fisher mengacu pada persamaan pertukaran (equation of exchange) yang durumuskan sebagai berikut:

$\mathbf{M V}=\mathbf{P T}$

\section{Nilai Tukar}

Nilai tukar adalah perbandingan nilai mata uang suatu negara terhadap mata uang negara asing lainnya (Thobarry, 2009). Definisi lain mengenai nilai tukar mata uang (exchange rate) adalah pertukaran antara dua mata uang yang berbeda, yaitu perbandingan nilai atau harga mata uang antara kedua mata uang yang berbeda tersebut. nilai tukar biasanya mengalami perubahan, perubahannya dapat berupa depresiasi maupun apresiasi. Depresiasi artinya terjadi penurunan harga mata uang domestik terhadap Dollar AS sedangkan apresiasi adalah kenaikan harga mata uang domestik terhadap Dollar AS (Anwary, 2011).

\section{Jumlah Uang Beredar}

Jumlah uang beredar (money supply) yaitu "the total quantity of money in the economy”. Jumlan atau keseluruhan uang dalam suatu perekonomian (Hubbard, 2005).

\section{Inflasi}

Inflasi dapat diartikan sebagai gejala kenaikan harga barang-barang yang bersifat umum dan terus menerus. (Rahardja dan Manurung, 2006). Dari definisi ini ada tiga syarat untuk dapat dikatakan telah terjadi inflasi. Pertama, adanya kenaikan harga. Kedua, kenaikan tersebut terjadi terhadap harga-harga barang secara umum. Ketiga, kenaikan tersebut berlangsung cukup lama. Dengan demikian kenaikan harga yang terjadi pada hanya satu jenis barang, atau kenaikan yang terjadi hanya sementara waktu tidak dapat disebut dengan inflasi. 
Jurnal Progres Ekonomi Pembangunan (JPEP)

Volume 6, Nomor 1. Tahun 2021

Page: $13-25$

http://ojs.uho.ac.id/index.php/JPEP

\section{Kerangka Konsep}

Konsep penelitian hubungan kausalitas nilai tukar, jumlah uang beredar dan inflasi dapat dapat dilihat pada Gambar 1.

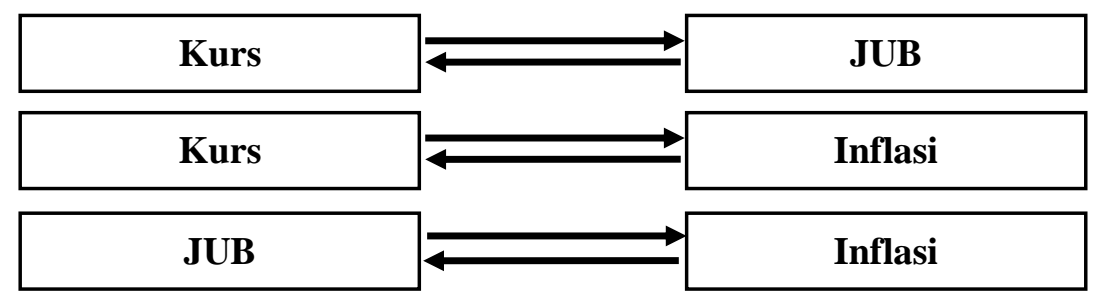

Gambar 1 Kerangka Konsep Penelitian

\section{METODE PENELITIAN}

Penelitian ini bertujuan untuk menganalisis hubungan kausalitas antara nilai tukar, inflasi dan jumlah uang beredar. Penelitian ini menggukana data sekunder time series bulanan selama periode 2010.1 sampai dengan 2018.12. Definisi variabel yang digunakan dalam penelitian ini adalah 1) Variabel nilai tukar (kurs) adalah harga mata uang Amerika Serikat (USD) terhadap harga mata domestik di Negara ASEAN-5; 2) Variabel inflasi yaitu tingkat inflasi menurut indeks harga konsumen dalam satuan persentase (\%); 3) Variabel jumlah uang beredar yaitu (M2) dalam satuan USD.

Vector Auto Regression (VAR) adalah pengembangan dari model Autoregressive Distributed Lag (ARDL), VAR melonggarkan asumsi variabel yang bersifat eksogen pada ARDL. Dalam kerangka VAR dimungkinkan untuk melakukan estimasi terhadap serangkaian variabel yang diduga mengalami endogenitas. Agar suatu Reduced Form dapat diestimasi dengan tidak bias dan konsisten serta dapat digunakan sebagai alat perumus kebijakan maka variabel eksogen tidak cukup bersifat stringly exogenus tetapi harus bersifat super exogenus. (Widarjono, 2013). Berukit adalah model umum VAR yaitu:

$\mathrm{KURS}_{\mathrm{t}}=\sum \beta_{1 \mathrm{i}}(\mathrm{KURS})_{\mathrm{t}-1}+\sum \lambda_{1 \mathrm{i}}(\mathrm{JUB})_{\mathrm{t}-1}+\sum$

$\mathrm{JUB}_{\mathrm{t}}=\sum \beta_{2 \mathrm{i}}(\mathrm{KURS})_{\mathrm{t}-1}+\sum \lambda_{2 \mathrm{i}}(\mathrm{JUB})_{\mathrm{t}-1}+\sum$

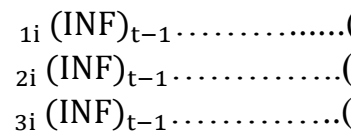

$\mathrm{INF}_{\mathrm{t}}=\sum \beta_{3 \mathrm{i}}(\mathrm{KURS})_{\mathrm{t}-1}+\sum \lambda_{3 \mathrm{i}}(\mathrm{JUB})_{\mathrm{t}-1}+\sum$

${ }_{3 i}(\mathrm{INF})_{\mathrm{t}-1}$

\section{Uji Stasioner Data (Uji Akar Root)}

Uji stasioner data dilakukan dengan menggunakan uji akar unit ADF. Hasil uji ADF sangat dipengaruhi oleh penjangnya kelambanan. Penjangnya kelambanan uji akar unit ADF dilakukan melalui kreteria Akaike Information Criterion (AIC). (Widarjono, 2013)

\section{Uji Kointegrasi}

Uji kointegrasi dilakukan untuk mengetahi keberadaan hubungan antar variabel. Pada langkah ini akan mengetahui apakah model yang kita bangun merupakan VAR tingkat deferensi jika tidak ada kointegrasi dan VECM bila terdapat kointegrasi dengan persamaan sebagai berikut: (Widarjono, 2013)

\section{Uji Panjang Lag Optimum}

Panjangnya lag optimum diperlukan untuk menangkap pengaruh dari setiap variabel terhadap variabel lain di dalam sistem VAR. Kriteria yang digunakan yaitu Akaike's Information Criterion (AIC). (Widarjono, 2013). 
Jurnal Progres Ekonomi Pembangunan (JPEP)

Volume 6, Nomor 1. Tahun 2021

Page: $13-25$

http://ojs.uho.ac.id/index.php/JPEP

\section{Uji Impulse Response Function}

Karena secara individual koifisien didalam model VAR sulit diinterprestasikan maka para ahli ekonometrika menggunakan analisis impulse response function. Impulse response function merupakan salah satu analisis penting didalam model VAR. analisis impulse response function melacak respon dari veriabel endogen didalam sistem VAR karena adanya goncangan (shocks) atau perubahan didalam variabel gangguan (e) (Widarjono, 2013)

\section{Uji Variance Decomposition}

Analisis variance decomposition ini menggambarkan relatif pentingnya setiap variabel didalam sistem VAR karena adanya shock. Variance decomposition berguna untuk mempredikasi kontribusi persentase varian setiap variabel karena adanya perubahan variabel tertentu didalam sistem VAR. (Widarjono, 2013)

\section{Uji Kausalitas Granger}

Uji Kausalitas Granger dimaksudkan untuk melihat pengaruh masing-masing variabel terhadap variabel lainnya satu persatu. Model ekonometrika yang dibangun berdasarkan hubungan antar variabel yang mengacu pada model dan digunakan untuk melihat hubungan kausalitas antar variabel. (Widarjono, 2013).

\section{Uji Estimasi VECM}

Spesifikasi VECM meresitriksi hubungan perilaku jangka panjang antar variabel yang ada agar konvergen ke dalam hubungan kointegrasi namun tetap memberikan perubahan-perubahan dinamis dalam jangka pendek. Terminologi kointegrasi ini dikenal sebagai korelasi kesalahan (error correction) karena bila terjadi deviasi terhadap keseimbangan jangka panjang akan dikoreksi secara bertahap melalui penyesuaian parsial jangka pendek secara bertahap. (Widarjono, 2013).

\section{HASIL DAN PEMBAHASAN}

Sebelum melakukan pengujian VAR pada variabel penelitian, terlebih dahulu dilakukan beberata tahapan pengujian yaitu uji stasioner data, uji kointegrasi dan uji panjang lag optimum sebagai berikut:

\section{Uji Stasioner Data}

Uji stasioneran data merupakan tahap yang paling penting dalam menganalisis data time series untuk melihat ada tidaknya maka dilakukan uji akar unit (unit root) yang terkandung pada masing-masing variabel sehingga hubungan antar variabel menjadi valid. Hasil uji stasioner data dapat dilihat pada Tabel 1.

Tabel 1

Hasil Uji Stasioner Data di Negara ASEAN-5

\begin{tabular}{ccccc}
\hline \multirow{2}{*}{ Variabel } & \multicolumn{2}{c}{ Tingkat Level } & \multicolumn{2}{c}{ Tingkat First Difference } \\
\cline { 2 - 5 } & Prob. & Ket. & Prob. & Ket. \\
\hline INFLASI & 0.0000 & Stasioner & 0.0000 & Stasioner \\
JUB & 0.0000 & Stasioner & 0.0000 & Stasioner \\
nilai tukar & 0.9239 & Tidak Stasioner & 0.0000 & Stasioner \\
\hline
\end{tabular}

Sumber : Data sekunder yang diolah, 2020 
Jurnal Progres Ekonomi Pembangunan (JPEP)

Volume 6, Nomor 1. Tahun 2021

Page: $13-25$

http://ojs.uho.ac.id/index.php/JPEP

Tabel 1 menunjukkan bahwa dalam seluruh variabel penelitian stasioner pada tingkat first Difference.

\section{Uji Kointegrasi}

Uji Kointegrasi dimaksudkan untuk menentukan ada tidaknya hubungan jangka panjang pada model yang dibangun. Hasil uji kointegrasi dapat dilihat pada Tabel 2.

Tabel 2

Hasil Uji Kointegrasi di Negara ASEAN-5

\begin{tabular}{ccccc}
\hline Hypothesized No. of CE(s) & Eigenvalue & Trace Statistic & $\mathbf{0 . 0 5}$ Critical Value & Prob.** \\
\hline None $*$ & 0.465435 & $\mathbf{6 4 4 . 5 7 9 5}$ & $\mathbf{2 9 . 7 9 7 0 7}$ & 0.0001 \\
At most $1 *$ & 0.294932 & $\mathbf{3 1 8 . 9 0 2 8}$ & $\mathbf{1 5 . 4 9 4 7 1}$ & 0.0001 \\
At most $2 *$ & 0.231883 & $\mathbf{1 3 7 . 1 8 2 7}$ & $\mathbf{3 . 8 4 1 4 6 6}$ & 0.0000 \\
\hline
\end{tabular}

Sumber : Data sekunder yang diolah, 2020

Tabel 2 menunjukkan bahwa dalam taraf uji 5 persen $(0,05)$, terdapat tiga rank variabel berhubungan kointegrasi. Hal tersebut terlihat dari nilai Trace Statistic lebih besar dari Critical Value 0,05, yang artinya bahwa penelitian ini memiliki hubungan dalam jangka panjang (kointegrasi) satu dengan lainnya. Oleh karena itu, estimasi VECM dalam penelitian ini dapat digunakan.

\section{Uji Lag Optimum}

Tabel 3

Hasil Uji Lag Optimum di Negara ASEAN-5

\begin{tabular}{cccllll}
\hline Lag & LogL & LR & FPE & AIC & \multicolumn{1}{c}{ SC } & HQ \\
\hline 0 & 1541.973 & NA & $5.71 \mathrm{e}-07$ & -5.862755 & -5.838393 & -5.853215 \\
1 & 1635.929 & 186.4810 & $4.13 \mathrm{e}-07$ & -6.186398 & $-6.088949^{*}$ & -6.148239 \\
2 & 1664.100 & $55.58939^{*}$ & $3.84 \mathrm{e}-07^{*}$ & $\mathbf{- 6 . 2 5 9 4 2 8 *}$ & -6.088892 & $-6.192650^{*}$ \\
\hline
\end{tabular}

Sumber : Data sekunder yang diolah, 2020

Tabel 3 menunjukkan bahwa panjang lag optimum pada variabel-variabel yang diamati berada pada lag ke 2 . Hal tersebut terlihat dari tanda bintang (*) yang secara umum berada di lag kedua. Sehingga lag yang digunakan dalam menguji kausalitas variabel inflasi, jumlah uang beredar dan nilai tukar adalah lag kedua.

\section{Uji Impulse Response}

Response of D(LOG_KURS) to D(LOG_KURS)

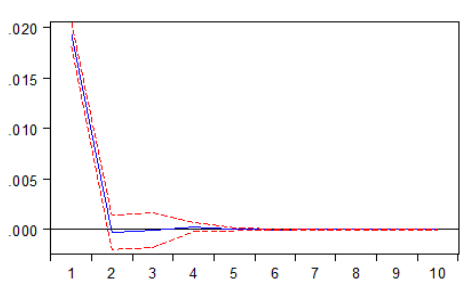

Response of D(LOG_KURS) to D(LOG_JUB)

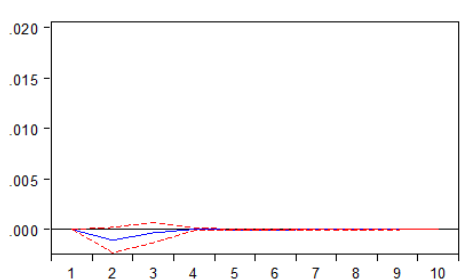

Response of D(LOG_KURS) to D(INF)

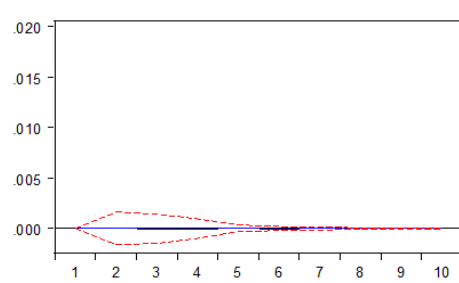

Gambar 2 Hasil Uji Impulse Response (KURS to KURS JUB dan Inflasi)

Sumber : Data sekunder yang diolah, 2020

Gambar 2 menunjukkan bahwa jumlah uang beredar merespon negatif adannya shocks dari nilai tukar di awal periode, namun nilai tukar merespon normal di periode berikitnya (nilai tukar to JUB). Hal yang sama terjadi pada inflasi yang merespon negatif adanya goncangan (shocks) nilai tukar (nilai tukar to INF). 
Jurnal Progres Ekonomi Pembangunan (JPEP)

Volume 6, Nomor 1. Tahun 2021

Page: $13-25$

http://ojs.uho.ac.id/index.php/JPEP

Response of D(LOG_JUB) to D(LOG_KURS)

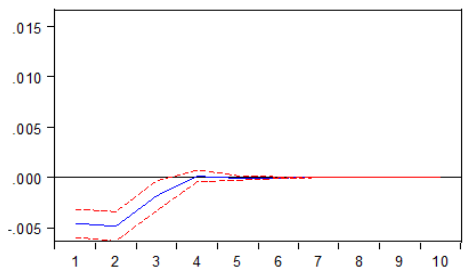

Response of D(LOG_JUB) to D(LOG JUB)

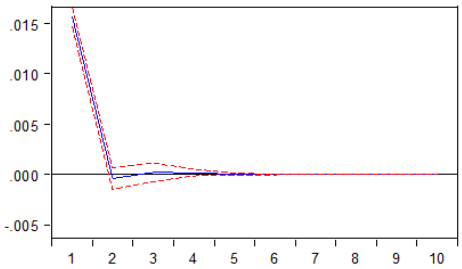

Response of D(LOG_JUB) to D(INF)

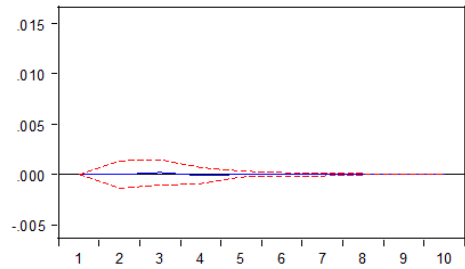

Gambar 3 Hasil Uji Impulse Response (JUB to KURS JUB dan Inflasi)

Sumber : Data sekunder yang diolah, 2020

Gambar 3 menunjukkan bahwa nilai tukar merespon negatif adannya shocks dari jumlah uang beredar di awal periode, namun nilai tukar merespon normal di periode berikitnya (JUB to nilai tukar). Hal berbeda terjadi pada inflasi yang merespon negatif adanya goncangan (shocks) jumlah aung beredar (JUB to INF).

Response of D(INF) to D(LOG KURS)

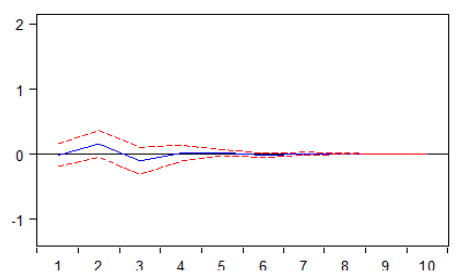

Response of D(INF) to D(LOG_JUB)

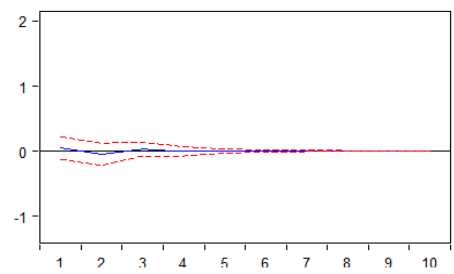

Response of D(INF) to D(INF)

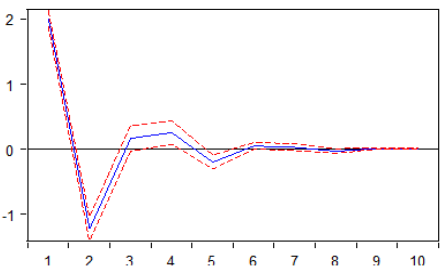

Gambar 4 Hasil Uji Impulse Response (Inflasi to KURS JUB dan Inflasi)

Sumber : Data sekunder yang diolah, 2020

Gambar 4 menunjukkan bahwa nilai tukar merespon positif adannya goncangan dari inflasi di awal periode, namun nilai tukar merespon negatif guncangan inflasi hingga periode pertengahan (INF to EKS). Hal yang sama terjadi pada jumlah uang beredar yang merespon negatif adanya guncangan Inflasi (INF to JUB).

Uji Varian Dekomposition

Tabel 4

Hasil Uji Varian Dekomposition Nilai Tukar

\begin{tabular}{ccccc}
\hline \multicolumn{5}{c}{ Variance Decomposition of D(LOG_nilai tukar) } \\
\hline Period & S.E. & D(LOG_KURS) & D(LOG_JUB) & D(INF) \\
\hline 1 & 0.019352 & 100.0000 & 0.000000 & 0.000000 \\
2 & 0.019382 & 99.71196 & 0.287994 & $4.83 \mathrm{E}-05$ \\
3 & 0.019385 & 99.68625 & 0.313579 & 0.000167 \\
4 & 0.019386 & 99.68601 & 0.313817 & 0.000170 \\
5 & 0.019387 & 99.68598 & 0.313843 & 0.000175 \\
6 & 0.019387 & 99.68597 & 0.313854 & 0.000176 \\
7 & 0.019387 & 99.68597 & 0.313854 & 0.000176 \\
8 & 0.019387 & 99.68597 & 0.313854 & 0.000176 \\
9 & 0.019387 & 99.68597 & 0.313854 & 0.000176 \\
10 & 0.019387 & 99.68597 & 0.313854 & 0.000176 \\
\hline
\end{tabular}

Sumber : Data sekunder yang diolah, 2020.

Dari hasil uji variance decomposition di atas, dapat dilihat bahwa varians nilai tukar dipengaruhi oleh nilai nilai tukar itu sendiri pada periode pertama sebesar 100 persen. Pada periode ke-5 variasi nilai prediksi nilai tukar sebesar 99,68 persen dan sisanya disumbangkan oleh inflasi 0,0001 persen dan jumlah uang beredar 0,31 persen. Pada periode ke-10 variasi nilai 
Jurnal Progres Ekonomi Pembangunan (JPEP)

Volume 6, Nomor 1. Tahun 2021

Page: $13-25$

http://ojs.uho.ac.id/index.php/JPEP

prediksi nilai tukar sebesar 99,68 persen dan sisanya disumbangkan oleh inflasi 0,0001 persen dan jumlah uang beredar 0,31 persen. Variance terbesar adalah jumlah uang beredar sebesar 0,31 persen pada periode ke-10, dan nilai inflasi memiliki variance terkecil terhadap nilai nilai tukar sebesar 4.83E-05 persen pada periode pertama.

Tabel 5

Hasil Uji Varian Dekomposition Jumlah Uang Beredar

\begin{tabular}{ccccc}
\hline \multicolumn{5}{c}{ Variance Decomposition of D(LOG_JUB) } \\
\hline Period & S.E. & D(LOG_KURS) & D(LOG_JUB) & D(INF) \\
\hline 1 & 0.016305 & 7.869509 & 92.13049 & 0.000000 \\
2 & 0.017021 & 15.39921 & 84.60075 & $3.48 E-05$ \\
3 & 0.017122 & 16.36443 & 83.62300 & 0.012564 \\
4 & 0.017123 & 16.36689 & 83.61589 & 0.017216 \\
5 & 0.017124 & 16.36789 & 83.61477 & 0.017343 \\
6 & 0.017124 & 16.36813 & 83.61432 & 0.017541 \\
7 & 0.017124 & 16.36811 & 83.61421 & 0.017678 \\
8 & 0.017124 & 16.36811 & 83.61420 & 0.017687 \\
9 & 0.017124 & 16.36811 & 83.61420 & 0.017690 \\
10 & 0.017124 & 16.36811 & 83.61420 & 0.017693 \\
\hline
\end{tabular}

Sumber : Data sekunder yang diolah, 2020

Tabel 5 menunjukkan varians jumlah uang beredar dipengaruhi oleh jumlah uang beredar itu sendiri pada periode pertama sebesar 92,13 persen dan sisanya dipengaruhi oleh nilai tukar sebesar 7,86 persen. Pada periode ke-5 variasi nilai prediksi jumlah uang beredar sebesar 83,61 persen dan sisanya disumbangkan oleh nilai tukar 16,36 persen dan inflasi 0,01 persen. Pada periode ke-10 variasi nilai prediksi jumlah uang beredar sebesar 83,61 persen dan sisanya disumbangkan oleh nilai tukar 16,36 persen dan inflasi 0,01 persen. Variance terbesar adalah nilai tukar sebesar 16,36 persen pada periode ke-6 dan inflasi memiliki variance terkecil yaitu sebesar 3.48E-05 persen pada periode ke-2.

Tabel 6

Hasil Uji Varian Dekomposition Inflasi

\begin{tabular}{ccccc}
\hline \multicolumn{5}{c}{ Variance Decomposition of D(INF): } \\
\hline Period & S.E. & D(LOG_KURS) & D(LOG_JUB) & D(INF) \\
\hline 1 & 2.005981 & 0.008111 & 0.055083 & 99.93681 \\
2 & 2.355091 & 0.456246 & 0.085969 & 99.45779 \\
3 & 2.363296 & 0.645587 & 0.101458 & 99.25296 \\
4 & 2.376904 & 0.641447 & 0.100954 & 99.25760 \\
5 & 2.385558 & 0.644636 & 0.100585 & 99.25478 \\
6 & 2.386132 & 0.649089 & 0.100915 & 99.25000 \\
7 & 2.386304 & 0.649253 & 0.100941 & 99.24981 \\
8 & 2.386513 & 0.649242 & 0.100926 & 99.24983 \\
9 & 2.386540 & 0.649344 & 0.100933 & 99.24972 \\
10 & 2.386542 & 0.649356 & 0.100934 & 99.24971 \\
\hline
\end{tabular}

Sumber : Data sekunder yang diolah, 2020

Tabel 6 menunjukkan varians inflasi dipengaruhi oleh inflasi itu sendiri pada periode pertama sebesar 99,93 persen dan sisanya dipengaruhi oleh nilai tukar sebesar 0,008 persen dan jumlah uang beredar 0,055 persen. Pada periode ke-5 variasi nilai prediksi inflasi sebesar 99,25 persen dan sisanya disumbangkan oleh jumlah uang beredar 0,1 persen dan nilai tukar 0,64 persen Pada periode ke-10 variasi nilai prediksi inflasi sebesar 99,24 persen dan sisanya 
Jurnal Progres Ekonomi Pembangunan (JPEP)

Volume 6, Nomor 1. Tahun 2021

Page: $13-25$

http://ojs.uho.ac.id/index.php/JPEP

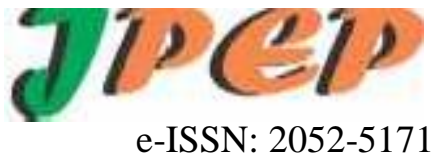

disumbangkan oleh jumlah uang beredar 0,1 persen dan nilai tukar 0,64 persen. Variance terbesar adalah nilai tukar sebesar 0,64 persen pada periode ke-10 dan nilai tukar juga yang memiliki variance terkecil terhadap inflasi sebesar 0,008 persen pada periode pertama.

\section{Uji Kausalitas Granger}

Uji kausalitas Granger dilakukan untuk mengetahui hubugan timbal balik antara variabel nilai tukar, jumlah uang beredar dan inflasi di Negara ASEAN-5. Hasil uji kausalitas Granger dapat dilihat pada Tabel 9.

Tabel 7

Hasil Uji Kausalitas Granger di Negara ASEAN-5

\begin{tabular}{lccc}
\hline Null Hypothesis: & Obs & F-Statistic & Prob. \\
\hline LOG_JUB does not Granger Cause LOG_KURS & 530 & 1.94774 & 0.1436 \\
LOG_KURS does not Granger Cause LOG_JUB & & 31.1676 & $\mathbf{2 . E - 1 3 *}$ \\
\hline INF does not Granger Cause LOG_KURS & 530 & 0.00573 & 0.9943 \\
LOG_KURS does not Granger Cause INF & & 3.83334 & $\mathbf{0 . 0 2 2 2 *}$ \\
\hline INF does not Granger Cause LOG_JUB & 530 & 5.27270 & $\mathbf{0 . 0 0 5 4}$ \\
LOG_JUB does not Granger Cause INF & & 15.0352 & $\mathbf{4 . E - 0 . *}$ \\
\hline
\end{tabular}

Sumber : Data sekunder yang diolah, 2020

Ket: * sig $5 \%$

Berdasarkan Tabel 7 dapat dijelaskan bahwa variabel yang memiliki hubungan kausalitas ialah variabel dengan nilai probabilitas lebih kecil dari $a=0,05$. Hasil pengujian kausalitas Granger ditemukan bahwa terdapat hubungan kausalitas satu arah antara nilai nilai tukar terhadap jumlah uang beredar di Negara ASEAN-5. Hasil penelitian tersebut memberikan informasi bahwa pelemahan nilai tukar mata uang domestik Negara ASEAN-5 terhadap Dolar Amerika Serikat akan meningkatkan jumlah uang beredar di Negara ASEAN-5. Namun tidak sebaliknya dimana peningkatan jumlah uang beredar tidak memberikan dampak terhadap pelemahan nilai tukar mata uang domestik Negara ASEAN-5 terhadap Dolar Amerika Serikat. Hasil penelitian tersebut bertolak belakang dengan pendapat yang dikemukakan Miskhin (2008) yang menjelaskan bahwa meningkatnya jumlah uang beredar akan mengakibatkan tingkat harga Amerika Serikat lebih tinggi dalam jangka panjang dan akan menurunkan nilai tukar dimasa mendatang. Penelitian lain yang sejalan dengan hasil penelitian tersebut dikemukakan oleh Putri, Yozza dan Devianto (2019) dan Hendayanti, dkk (2017) yang menyatakan bahwa perubahan nilai tukar akan berdampak terhadap jumlah uang yang beredar.

Pengujian kausalitas Granger menunjukkan bahwa terdapat hubungan kausalitas satu arah antara nilai tukar terhadap inflasi di Negara ASEAN-5. Hasil tersebut memberikan gambaran bahwa pelemahan nilai mata uang domestik terhadap mata uang Dolar Amerika Serikat akan meningkatkan inflasi yang terjadi di Negara ASEAN-5. Namun hal tersebut tidak terjadi sebaliknya dimana peningkatan inflasi tidak menyebabkan pelemahan nilai mata uang domestik terhadap mata uang Dolar Amerika Serikat di Negara ASEAN-5. Penelitian lain yang menyatakan hal yang serupa dikemukakan oleh Ningsi dan Kristiyanti (2018); Nurrohim (2013); Putri, dkk (2019); Musyaffa dan Sulasmiyati (2017).

Pengujian kausalitas Granger yang dilakukan di Negara ASEAN-5 menunjukkan bahwa terdapat hubungan kausalitas antara jumlah uang beredar dan inflasi. Hasil tersebut memberikan informasi bahwa peningkatan jumlah uang beredar akan meningkatkan inflasi di Negara ASEAN-5. Begitu pila sebaliknya peningkatan inflasi yang terjadi akan meningkatkan jumlah uang beredar di Negara ASEAN-5. Hasil penelitian ini sejalan dengan teori fisher dimana teori 
Jurnal Progres Ekonomi Pembangunan (JPEP)

Volume 6, Nomor 1. Tahun 2021

Page: $13-25$

http://ojs.uho.ac.id/index.php/JPEP

ini menyoroti peranan dalam proses inflasi dari jumlah uang yang beredar dan psikologi (harapan) masyarakat mengenai kenaikan harga. (Marshall and Swanson, 1980 dalam Natsir, 2012). Hasil penelitian yang menemukan hal yang sama dikemukakan oleh Afrizal (2017); Anwar dan Ansari (2018); Cahyadin (2012); Putra dan Meydianawati (2015); Ningsih dan Kristiyanti (2018) dan Putri, dkk (2019).

\section{Estimasi VECM}

Tabel 8

Hasil Estimasi VECM Jangka Pendek di Negara ASEAN-5

\begin{tabular}{cccc}
\hline Error Correction: & D(LOG_KURS) & D(LOG_JUB) & D(INF) \\
\hline D(LOG_KURS(-1)) & -0.030801 & -0.256448 & 6.860730 \\
& $(0.04508)$ & $(0.03779)$ & $(4.47536)$ \\
& {$[-0.68329]$} & {$[-6.78605]^{*}$} & {$[1.53300]$} \\
D(LOG_KURS(-2)) & -0.025315 & -0.107954 & 0.052828 \\
& $(0.04716)$ & $(0.03954)$ & $(4.68250)$ \\
D(LOG_JUB(-1)) & {$[-0.53675]$} & {$[-2.73027]^{*}$} & {$[0.01128]$} \\
& -0.061330 & -0.037688 & 2.495974 \\
& $(0.04086)$ & $(0.03426)$ & $(4.05670)$ \\
D(LOG_JUB(-2)) & {$[-1.50099]$} & {$[-1.10022]$} & {$[0.61527]$} \\
& -0.020589 & -0.011509 & 3.495775 \\
D(INF(-1)) & $(0.03275)$ & $(0.02745)$ & $(3.25126)$ \\
& {$[-0.62872]$} & {$[-0.41922]$} & {$[1.07520]$} \\
& 0.000298 & -0.000665 & -0.389688 \\
D(INF(-2)) & $(0.00052)$ & $(0.00043)$ & $(0.05139)$ \\
& {$[0.57605]$} & {$[-1.53252]$} & {$[-7.58277]^{*}$} \\
& 0.000144 & -0.000247 & -0.175993 \\
& $(0.00044)$ & $(0.00037)$ & $(0.04343)$ \\
R-squared & {$[0.32952]$} & {$[-0.67408]$} & {$[-4.05273]^{*}$} \\
\hline S & 0.006882 & 0.104942 & 0.353503 \\
\hline
\end{tabular}

Sumber : Data sekunder yang diolah, 2020

* Pengaruh Jangka Pendek

Tabel 8 menunjukkan bahwa jumlah uang beredar dipengaruhi oleh nilai tukar satu dan dua periode sebelumnya. Hasil lain yaitu inflasi dipengaruhi oleh tingkat inflasi itu sendiri pada satu dan dua periode sebelumnya yang terjadi di Negara ASEAN-5 
Jurnal Progres Ekonomi Pembangunan (JPEP)

Volume 6, Nomor 1. Tahun 2021

Page: $13-25$

http://ojs.uho.ac.id/index.php/JPEP

Tabel 9

Hasil Estimasi VECM Jangka Panjang di Negara ASEAN-5

\begin{tabular}{cccc}
\hline Cointegrating Eq: & LOG_KURS & LOG_JUB & INFLASI \\
\hline LOG_KURS & 1.000000 & -0.054374 & 0.075196 \\
& & $(0.04348)$ & $(0.06792)$ \\
& & {$[-1.25057]$} & {$[1.10711]$} \\
LOG_JUB & -18.39111 & 1.000000 & -1.382942 \\
& $(3.76176)$ & & $(0.25617)$ \\
& {$[-\mathbf{4 . 8 8 8 9 7}]^{*}$} & & 1.000000 \\
INFLASI & 13.29854 & -0.723096 & \\
& $(1.79052)$ & $(0.07805)$ & \\
& {$[\mathbf{7 . 4 2 7 1 9}]^{*}$} & {$[-\mathbf{- 9 . 2 6 4 2 0}]^{*}$} & \\
C & 334.1905 & -18.17131 & 25.12987 \\
\hline
\end{tabular}

Sumber : Data sekunder yang diolah, 2020

* Pengaruh Jangka Panjang

Tabel 9 menunjukkan bahwa dalam jangka panjang inflasi dan jumlah uang beredar berpengaruh terhadap nilai tukar telihat dari masing-masing nilai t-hitung sebesar 4,88897 dan 7,42719 lebih besar dari nilai t-tabel sebesar 1,9644. Variabel jumlah uang beredar dalam jangka panjang dipengaruhi oleh nilai infalsi nilai t-hitung sebesar 9,26420 lebih besar darinilai t-tabel sebesar 1,9644. Jumlah uang beredar berpengaruh terhadap inflasi telihat dari nilai thitung sebesar 5,39861 lebih besar dibandingkan nilai t-tabel sebesar 1,9644.

\section{KESIMPULAN}

Berdasarkan hasil dan pembahasan mengenai hubungan kausalitas dan hubungan jangka panjang dan jangka pendek antara nilai tukar, jumlah uang beredar dan inflasi di Negara ASEAN-5 maka dapat ditari kesimpulan bahwa: (1) Terdapat hubungan kausalitas antara jumlah uang beredar dan inflasi serta hubungan kausalitas satu arah nilai tukar terhadap jumlah uang beredar dan nilai tukar terhadap inflasi; (2) Dalam jangka pendek nilai tukar berpengaruh signifikan terhadap jumlah uang bereda. Dalam jangka panjang jumlah uang beredar dan inflasi berpengaruh signifikan terhadap nilai tukar, jumlah uang beredar berpengaruh signifikan terhadap inflasi serta inflasi berpengaruh signifikan terhadap jumlah uang beredar.

\section{DAFTAR PUSTAKA}

Anwar, Khairil dan Ansari. 2018. Analisis Hubungan Kausalitas Antara Jumlah Uang Beredar, BI Rate Dan Inflasi Di Indonesia Tahun 2010-2016. Jurnal Ekonomi Regional Unimal Vol. 01 No. 3. Hlm. 9-18.

Anwary, Ahmad Amiruddin. 2011. Prediksi nilai tukar Rupiah Terhadap Dollar Amerika Menggunakan Fuzzy Time Series. Program Studi Teknik Informatika Jurusan Matematika. Fakultas Matematika dan Ilmu Pengetahuan Alam. Universitas Diponegoro. Semarang.

Burhanuddin. 2020. Analisis Hubungan Fundamental Makroekonomi di Negara-Negara ASEAN. Tesis. Program Pascasarjana Universitas Halu Oleo Kendari. 
Jurnal Progres Ekonomi Pembangunan (JPEP)

Volume 6, Nomor 1. Tahun 2021

Page: $13-25$

http://ojs.uho.ac.id/index.php/JPEP

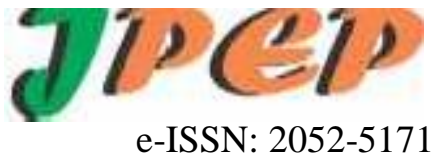

Cahyadin, Malik dan Agni Alam Awirya. 2012. Interaksi Antara Indikator Moneter dan Indikator Makroekonomi di Indonesia Tahun 2005-2010. Jurnal Ekonomi Kuantitatif Terapan Vol. 5 No. 2. Hlm. 101-108.

Hario, Aji Ahrtono. 2010. Pengaruh Jumlah Uang Beredar dan nilai tukar Terhadap Tingkat

Inflasi di Indonesia Sebelum dan Setelah Krisis Global 2008. Media Ekonomi. Vol. 18 No. 3. Hlm. 1-22.

Hazizah, Nurul. Zainuri dan Viphindrartin, Sebastiana. 2017. Pengaruh JUB, Suku Bunga, Inflasi, Ekspor dan Impor terhadap nilai tukar Rupiah atas Dollar Amerika Serikat. Journal Ekonomi Bisnis dan Akutansi. Volume IV (1). Hlm. 97-103.

Hendayanti, Ni Putu Nanik. Nurhidayati, Maulida dan Nugrahini, Dwi Setya. 2017. Analisis Pengaruh nilai tukar Rupiah terhadap Jumlah Uang Beredar dengan Pendekatan Error Correction Model (ECM). Konferensi Nasional Sistem \& Informatika. STMIK STIKOM Bali, 10 Agustus 2017. Hlm. 186-190.

Hubbard , R. Glenn. 2005. Money the Financial System and the Economy Paperback

Mishkin, Frederic S. 2008. Ekonomi, Uang, Perbankan dan Pasar Keuangan Edisi 8. Jakarta: Salemba Empat

Musyaffa', Arfidan Sabiq dan Sulasmiyati, Sri. 2017. Pengaruh Jumlah Uang Beredar, Inflasi Dan Suku Bunga Terhadap nilai tukar Rupiah Terhadap Dollar (Studi Pada Bank Indonesia Periode 2011-2015). Jurnal Administrasi Bisnis (JAB) Vol. 50 No. 4. Hlm.19-24.

Natsir, M. 2012. Ekonomi Moneter Teori dan Kebijakan. Semarang: Polines Semarang

Ningsi, Suhesti dan Kristiyanti, LMS. 2018. Analisis Pengaruh Jumlah Uang Beredar, Suku Bunga, Dan nilai tukar Terhadap Inflasi Di Indonesia Periode 2014-2016. Jurnal Ekonomi Manajemen Sumber Daya Vol. 20, No. 2. Hlm. 96-103.

Nurrohim, Muh. 2013. Analisis Kausalitas Volatilitas nilai tukar Mata Uang Dengan Kinerja Sektor Keuangan Dan Sektor Rill. Economics Development Analysis Journal. EDAJ 2 (4). Hlm. 351-366.

Putra, I Komang dan Luh Gede Meydianawati. 2015. Analisis Vector Auto Regressive Terhadap Kausalitas Inflasi Dan Jumlah Uang Beredar Indonesia. E-Jurnal EP Unud, Vol. 4 (3). Hlm. 180-189.

Putri, Nadya Risna Hazmira Yozza dan Dodi Devianto. 2019. Hubungan kausalitas nilai tukar rupiah Terhadap dollar amerika serikat, jumlah Uang beredar dan tingkat inflasi. Jurnal Matematika UNAND Vol. VIII No. 1 Hal. 232-241.

Rahardja, Prathama dan Manurung, Mandala. 2011. Uang, Perbankan dan Ekonomi Moneter. Jakarta: Fakultas Ekonomi Universitas Indonesia

Reksoprayitno, Soediyono. 2009. Pengantar Ekonomi Makro, Edisi Pertama, Cetakan Kedua. Yogyakarta: BPFE UGM

Theodores maniela Langi, Vecky Masinambow, Hanly Siwu. 2014. Analisis Pengaruh Suku Bunga BI, Jumlah Uang Beredar dan Tingkat nilai tukar Terhadap Tingkat Inflasi di Indonesia. Jurnal Berkala Ilmiah Efisiensi. Vol. 14 No. 2. Hlm. 44-58.

Thobarry, Ahmad. 2009. Analisis Pengaruh nilai tukar, Suku Bunga, Laju Inflasi, dan Pertumbuhan GDP Terhadap Indeks Harga Saham Sektor Properti. Tesis. Semarang: Program Studi Magister Manajemen Universitas Diponegoro 
Jurnal Progres Ekonomi Pembangunan (JPEP)

Volume 6, Nomor 1. Tahun 2021

Page: $13-25$

http://ojs.uho.ac.id/index.php/JPEP

Widarjono, Agus. 2013. Ekonometrika Pengantar dan Aplikasinya Disertai Panduan EViews. Edisi Keempat. Yogyakarta: UPP STIM YKPN.

https://www.ceicdata.com/id/indicator/indonesia/money-supply-m2. Data jumlah uang beredar. Diakses 27 Juli 2020

https://www.investing.com/currencies/idr-usd. Data nilai tukar. Diakses 27 Juli 2020

https://tradingeconomics.com/indonesia/inflation-cpi. Data inflasi. Diakses 27 Juli 2020 